\title{
Effects of Declining Paper Industry on Nigeria Economy and the Way Forward
}

\author{
Egbewole Zaccheaus Tunde ${ }^{1, *}$, Rotowa Odunayo James ${ }^{2}$ \\ ${ }^{1}$ Department of Forestry, Wildlife and Ecoutourism, Nasarawa State University Keffi, Keffi, Nigeria \\ ${ }^{2}$ Department of Forest Production and Products, Faculty of Renewable Natural Resources, University of Ibadan, Ibadan, Nigeria
}

\section{Email address:}

tundeegbe@gmail.com (E. Z. Tunde), tundeegbe@yahoo.com (E. Z. Tunde)

${ }^{*}$ Corresponding author

\section{To cite this article:}

Egbewole Zaccheaus Tunde, Rotowa Odunayo James. Effects of Declining Paper Industry on Nigeria Economy and the Way Forward. American Journal of Agriculture and Forestry. Vol. 5, No. 6, 2017, pp. 181-187. doi: 10.11648/j.ajaf.20170506.11

Received: August 20, 2017; Accepted: August 29, 2017; Published: November 6, 2017

\begin{abstract}
Nigeria paper industry has not reached the optimum performance level expected of it by planners despite the huge money spent on the establishment of pulp and paper mills in the country before it finally stop production in 1994 due to the high dependence on foreign inputs. This paper examines the problems militating against pulp and paper production in Nigeria and highlights the pathway for promoting optimal pulp and paper capacities locally. Commonly used tree species for pulp and paper production like Gmelina arborea, Pinus caribaea etc, are threatened due to high rate of deforestation and increasing demand of their wood for other economic purposes. Hence, none of the three primary pulp and paper mills established in the country by government within 1960's to 1970's performed optimally except The Nigerian Paper Mill, Jebba in the 1980's as pulp and paper importation reduced drastically as a result of high capacity utilization in the mills. In 1985 and 1986, capacity utilization in Nigerian Paper Mill was $62.3 \%$ in 1960's and 66.17\% in the 1960's. In 1996, The Nigeria Newsprint Manufacturing Company (NNMC), Oku Iboku also stopped production leading to complete dependence on importation of paper and paper products. In 2006, the mills were privatized, and, currently more than 500 billion naira is expended on importation of paper products annually. The only and urgent remedy is to put in place machinery for massive sustainable wood production. Likewise, the use of indigenous wood species and agricultural residues should be encouraged for long fiber pulp production. Efforts should further be made for a stable power supply from national grid to ensure the sustainability of industrial growth most especially in the pulp and paper industries.
\end{abstract}

Keywords: Forest Products, Pulp, Paper, Newsprint, Manufacturing, Industry

\section{Introduction}

Pulp and paper products have been the largest forest products imported into Nigeria. For many years, the need for the development of pulp and paper capacities in developing countries were of limited interest as a result of the stability experienced in the global pulp and paper market [1]. However, as the global economy began to expand in the late 1950's through the 1970's and the market for pulp, paper and paperboard began to increase, developing countries began to engage in pulp and paper manufacturing. This development was encouraged by four main factors. These include the need to make use of available raw materials and reduce foreign exchange expenditure; to protect local consumers from the high import prices; to develop local industry and provide employment; and, to promote national industrial development aspirations [1].

However, the disadvantages of establishing pulp and paper mills in developing countries were observed to be many. Among these are relatively small markets, low range of products output, high dependence on imported inputs resulting in higher cost of operation compared to similar mills in developed countries, dependence on foreign management and technical personnel; high cost of energy and imported chemicals, coupled with low exchange value of domestic currencies concerns [2]. 


\subsection{History of Pulp and Paper Products and Production in Nigeria}

The pulp and paper industry in Nigeria was one of the major industries that performed well in the 70-80's before the oil boom era as self-sufficiency in paper production was one of the major cardinal objectives of the Nigerian government. This was evidenced by the local establishment of three integrated pulp and paper mills between 1969-1976. Two of the mills: the Nigeria Paper Mill, Jebba (NPM) and the Nigeria Newsprint Manufacturing Company (NNMC), Oku Iboku, performed optimally and paper importation drastically reduced in the 1980's [3]. The Nigeria Paper Mill, Jebba's actual production in 1985 was $40,480 \mathrm{Mt}$ increased to $42,960 \mathrm{Mt}$ in 1986 , representing $62.3 \%$ and $66.17 \%$ capacity utilization respectively. This pattern of capacity utilization was also experienced at the Nigeria Newsprint Manufacturing Company, (NNMC), Oku- Iboku about the same period. The volume of production at NNMC rose from 28,927Mtin 1989, and to 37,581Mt in 1990 [4]; [5]. Due to establishment of the NNMC, importation of newsprints reduced drastically from $17.5 \%$ in 1986 to $12.5 \%$ in 1987 respectively and completely stoppedin 1988 [3]. However, the downturn in the economy in the 1990's revealed the structural weakness of government led industrialization strategy. The mills which were mostly owned by the Federal Government depended extensively on foreign inputs inform of long fiber pulp, management and technical expertise and spare parts. Thus, the integrated mills became convulsed in the 1990's and capacity utilization completely stopped. Capacity utilization at the Nigeria Paper Mill became as low as $2.5 \%$ in the early 1990 's until the mill stopped production in 1996 [6].

Iwopin Pulp and Paper Company, being the third pulp and paper mill company was also established in 1976 to produce fine writing, printing and cultural papers. It was abandoned in 1983, when the mill installation was at about $85 \%$ completion, and up till the time it was shut down in 1998, the mill never produced up to $5 \%$ of it's installed capacity [7]; [8]. In line with the privatization agenda of the Federal Government, the primary pulp and paper mills were privatized in 2006. This situation has seriously affected the pulp and paper industry in Nigeria.

Table 1. Demand and Supply statistics on some of the major raw materials required in the pulp and paper sector in 2005.

\begin{tabular}{llllll}
\hline S/N & Raw Materials & National Production & National Demand & Supply gap & Supply gap (\%) \\
\hline 1 & Long Fiber Pulp (BDMT) & 0 & $85,668.1$ & $85,668.1$ & 100 \\
2 & Short Fiber Pulp (BDMT) & 0 & $280,000.0$ & $280,000.0$ & 100 \\
3 & Waste Paper & $74,000.0$ & $100,000.0$ & $26,000.0$ & 26 \\
4 & Kraft Paper & 0 & $80,000.0$ & $80,000.0$ & 100 \\
5 & Fluiting paper & 0 & $20,000.0$ & $20,000.0$ & 100 \\
6 & Newsprint & 0 & $250,000.0$ & $250,000.0$ & 100 \\
7 & Sodium sulphate (tones) & 0 & 2,600 & 2,600 & 100 \\
8 & Sodium sulphate (tones) & 0 & 6,000 & 180,000 & 100 \\
9 & Soda ash (tones) & 0 & 55 & 55 & 100 \\
10 & Sodium Hydroxide & 0 & 144,260 & 144,260 & 100 \\
\hline
\end{tabular}

Source: [8].

Table 2. Summary of Capacity Utilization in the Pulp, Paper, Paper Products, Printing and Publishing Sector (2003-2006).

\begin{tabular}{|c|c|c|c|c|c|c|c|}
\hline \multirow[b]{2}{*}{$\mathbf{S} / \mathbf{N}$} & \multirow[b]{2}{*}{ Sub-Sector } & \multirow[t]{2}{*}{$\begin{array}{l}\text { Installed } \\
\text { Capacity(Mt) } \\
\end{array}$} & \multicolumn{4}{|c|}{ Capacity Utilization (\%)Year } & \multirow[t]{2}{*}{$\begin{array}{l}\text { Average Capacity } \\
\text { Utilization (\%) } \\
\end{array}$} \\
\hline & & & 2003 & 2004 & 2005 & 2006 & \\
\hline Primary Paper & (Fiber sources) & $1,169,145.00$ & 4.92 & 5.98 & 6.33 & 6.84 & 6.38 \\
\hline Primary Paper & (Chemicals) & $105,262,517.00$ & 0.00 & 0.00 & 0.00 & 0.00 & 0.00 \\
\hline Stationery, (Paper) & Light/Heavy Packaging & $3,467,400.00$ & 68.44 & 75.87 & 84.81 & 88.07 & 82.92 \\
\hline Stationery, (Boards) & Light/Heavy Packaging & $463,410.00$ & 79.62 & 85.06 & 85.71 & 87.61 & 84.53 \\
\hline Stationery, (Chemicals) & Light/Heavy Packaging & $571,093.00$ & 76.54 & 80.24 & 85.71 & 87.61 & 84.53 \\
\hline Stationery, (Miscellaneous) & Light/Heavy Packaging & $10,203,418.00$ & 63.64 & 59.67 & 60.61 & 62.64 & 60.97 \\
\hline \multicolumn{2}{|c|}{ Printing and Publishing (Paper) } & $42,903.00$ & 17.64 & 19.24 & 20.68 & 22.222 & 2.71 \\
\hline \multicolumn{2}{|c|}{ Printing and Publishing (Boards) } & $499,271.00$ & 58.81 & 61.18 & 63.16 & 65.88 & 63.41 \\
\hline \multicolumn{2}{|c|}{ Printing and Publishing (Chemicals) } & $20,808.00$ & 46.18 & 46.74 & 47.49 & 47.96 & 47.40 \\
\hline \multicolumn{2}{|c|}{ Printing and Publishing (Miscellaneous) } & $25,573.00$ & 88.98 & 89.18 & 89.40 & 89.83 & 89.47 \\
\hline \multicolumn{3}{|c|}{ Total Annual Capacity Utilization (\%) } & & & & & 54.18 \\
\hline
\end{tabular}

Source: [6]

\subsection{Demand and Supply Statistics on Some of the Major Raw Materials and Capacity Utilization in the Pulp, Paper Products, Printing and Publishing Sector}

The supply gap for long fiber pulp, kraft paper, newsprint, bank paper etc, were met through importation in 2005 (Table 1). Also, the pulp and paper capacity utilization in the primary pulp and paper sub-sector (fiber source) increased from $4.92 \%$ in 2003 to $6.33 \%$ in 2005 and to $6.84 \%$ in 2006 , resulting in average capacity utilization of $6.38 \%$ in the primary pulp and paper subsector (Table 2). The very low capacity utilization in this sub-sector is attributable to status of the three primary pulp and paper mills as the activity in the subsector was only sustained by waste paper recycling [8]. 
Local production capacity of chemical raw materials remained nil throughout the period (between 2003-2006). The, capacity utilization of the stationary (paper) in 2003 was $68.44 \%$, this increased to $75.87 \%$ in $2004,84.81 \%$ in 2005 and to $88.07 \%$ in 2006 . While, the capacity utilization of stationary (board) in 2003 was $79.62 \%$, this increased to $85.06 \%$ in $2004,85.57 \%$ in 2005 and $87.39 \%$ in 2006 . The overall capacity utilization in the entire sector was $54.18 \%$ [8]. (Table 2). The high capacity utilization recorded by the printing, stationary and other subsectors apart from primary paper manufacturers was mainly due to high exchange rate expended on paper imports. This became important in view of the need to satisfy the requirements of the Universal Basic Education as promulgated by government coupled with increase in publicity generated by political activities in the country. It was observed that, apart from the $26 \%$ of waste paper raw material which was sourced locally for production of tissue papers, the demands for the rest $74 \%$ other raw materials (paper, chemicals, etc.) were largely met through importation [8]. Same trend is still the order of the day in the pulp and paper industry in Nigeria.

\section{Challenges Faced by Nigeria Paper Mills}

The plight of the stationary, light packaging and the printing and publishing sub-sectors of the pulp and paper industry have not been radically different from that of primary paper manufacturing [8]. Today, just as in the 70's, 80 's and 90's the challenges of the pulp and paper industry includes:

i. Problem of high foreign exchange: High foreign exchange level caused by continuous depreciation of the naira and collapsed infrastructure.

ii. Poor power supply: Poor power supply due to skyrocketing prices of diesel thereby increased input of paper production.

iii. Poor finance: Pulp and paper mills in Nigeria suffered gross underfunding. Government often time do not meet their budget estimation and whenever fund are released, they are often late in coming.

iv.Inadequate manpower: Like in all cadres, there was generally shortage of manpower in Nigeria paper mills (vocational, technical and professionals). The government should put in place deliberate effort to recruit and/or to train people to fill these gaps.

v. Inadequate or obsolete equipment: [9]. reported that the state of forest services lack the necessary equipment and tools, [10] also noted that the paper mills in Nigeria lacks the necessary equipment and tools to meet contemporary development challenges.

vi.Inadequate research efforts: Inadequate research efforts were not done into conversion and utilization of pulp and paper and mills development in Nigeria.

vii. Poor policy and policy reversal: sometimes, there are difficulties in understanding the policy statement because of non-clarity as they affect pulp and paper industry in Nigeria [11].

viii.Problem of over dependent on importation of pulp and paper product: The integrated pulp and paper mills in Nigeria depend overwhelmingly on imported long fiber pulp.

Disadvantages of Over Dependent on Importation of Pulp and Paper Product

The integrated pulp and paper mills in Nigeria depend overwhelmingly on imported long fiber pulp. The forests in Nigeria consists predominantly mixed tropical hardwood species whose fiber lengths are short varying from $0.8 \mathrm{~m}$ to $1.6 \mathrm{~mm}$. [12] Reported that, fiber length is an important factor influencing strength development in paper. [13] Also noted that the differences observed in comparing the properties of paper from different fiber sources are mainly due to the influence of fiber characteristics.

According to Raw Material Research and Development Council [6], impact on this negative trend in the pulp and paper industry more sufficiently that the sector was losing $400 \mathrm{bn}$ yearly to paper products importation. The amount which could be saved over the major operating form is revived. Estimate of import of finished products in the sector amount is $400 \mathrm{bn}$ annually and at the same time create over 200,000 job opportunity for young Nigerians. According to [5], the printing and publishing sub-sectors experienced a general increase in the production of document, while booklet type products relating from 1999 to 2004. This is rather a good performance of the printing and publishing subsector; CBN said was a direct consequence of the high level of political activities in the country and the exploitation in student turnover given zero capacity utilization in the primary paper manufacturing sub-sector. This performance was sustained through importation of critical raw material which has all along been described as unhealthy for the economy.

\section{The Way Forward; Strategies for Maximizing Pulp and Paper Production}

Without any doubt, there is need for production of optimal quantity and quality of pulp and paper products. This has over the year of inactive operation of the paper mill been recognized locally. Some of the approaches that may be instituted sequel to the privatization of the three integrated pulp and paper mills are;

i. Exploring the optimal performance of Pinus Species and other potential long fiber species

One of the strategic plans of the Nigerian government for the development of the paper industry was to promote plantation establishment of Pinus species for long fiber pulp production. In view of this, seeds were imported and established in plantations in various locations within the savanna and forest ecologies in Nigeria [14]. While some successes were recorded at the early stage of the project, the 
exercise later turned out to be a failure [15]. One of the major causes of the failure was the inability of the micorrhiza imported to become established in the field [16]. The micorrhiza functions as an absorbing organ for the plant and failure of pine plantations and nurseries were attributed to the lack of development of the micorrhiza association [17]. The failure of the miccorhiza to become established was associated with high temperature [15]. According to [17], in the savanna region of Nigeria, pines have to be initially inoculated with micorrhiza if satisfactory results were to be obtained. Despite this and several other methods that were tried, the project did not record adequate success. Thus, [18] summarized that the failure of the project was due to lack of suitable miccorhiza in Nigerian soils. As a result, despite the efforts of pioneer foresters in Nigeria, Pinus species can only be found on experimental plots in locations such as Afaka in Kaduna State and Miango in Jos, Ijaye Forest Reserve in Oyo State and in a number of other isolated areas [19].

ii. Utilization of Kenaf as a Raw Material for Long Fiber Pulp Production

Kenaf is currently being explored in most developed and developing countries as a viable raw material for pulp and paper production. In Nigeria, efforts have been made to promote kenaf utilization in the pulp and paper industry. [20] reported the mean fiber length of locally grown kenaf to be $2.90 \mathrm{~mm}$ while the fiber diameter was reported as $28.16 \mu \mathrm{m}$; lumen width, $6.08 \mu \mathrm{m}$; and cell wall thickness; $11.04 \mu \mathrm{m}$ respectively. While, in Malaysia; due to the potential commercial value of kenaf, the government allocated RM 12 million for research and development of kenaf based industry under the $9^{\text {th }}$ Malaysian development plan (2006-2010) [21] It had been observed that, the average fiber length, diameter, lumen width and cell wall thickness of the kenaf sample compared with the fiber dimensions of kenaf varieties reported by [22], and [23]. It was also observed to be comparable to the range of $2.7 \mathrm{~mm}$ to $4.6 \mathrm{~mm}$ for softwood tracheid [24]. Consequently, [20]. Opined that kenaf fiber could go a long way in alleviating the problems posed by a shortage of long fiber pulp to Nigeria pulp and paper mills.

iii. Development and Utilization of Long Fiber Pulp from Sterculia setigera

One of the major indigenous raw materials reported locally to have long fiber characteristics is Sterculia setigera. [25] Reported the fiber length to be $2.41 \mathrm{~mm}$. As a result of its long fiber length value, $S$. setigera can be regarded as a long fiber wood species in accordance with the classification of [26]. Consequently, S. setigera may produce pulp with properties reminiscent to those of imported long fiber pulp. Its mean wood density was $249 \mathrm{~kg} / \mathrm{m}^{3}$ [27]. Although, this density value is within the acceptable range for pulp and paper production, it is considered low and may lead to low pulp yield. The low density may place $S$. setigera at a disadvantage as pulp wood raw materials when the economy of optimal digester packing is considered [13].

iv.Utilization of Sterculia oblongafor Long Fiber Pulp Production
Sterculia oblonga is also one of the indigenous wood species that has been reported to have long fiber length. [27] in a preliminary work carried out on Sterculia oblong from Nigeria showed the fiber characteristics of the plant species to be as presented in Table 3. The average fiber length of the wood species is $2.07 \mathrm{~mm}$ which is higher than in most hardwood species. The alcohol benzene solubility is $3.6 \%$ and the wood density was $260 \mathrm{~kg} / \mathrm{m}^{3}$ (Table 3 ). The strength properties of unbleached kraft paper at K-NO 10 were also reported by [27] to be within acceptable range when compared with commercial kraft paper at Nigeria Paper Mill. In the light of the above, the development of the Nigeria Pulp and Paper industry may be premised on long fiber raw materials sourcing from plantation grown Sterculiaoblonga.

v. Bamboo Utilization for Pulp and Paper Production

Despite bamboo's ubiquity in some parts of Nigeria, little or no attention has been directed towards its development while bamboo is a popular raw material for pulp and paper making in countries such China, India and Malaysia. In recent study, [28] indicated that bamboo is widely distributed in the south and middle belts regions of Nigeria. Despite this, bamboo utilization for pulp and paper production locally was inconsistent as it was dropped by the Nigeria Paper Mill, Jebba in 1980's as a result of silica deposition problems experienced by the mill. [29] reported that, the hot water solubility of the species ranged from $5.37 \%-7.28 \%$, the cold water solubility from $5.37 \%-7.28 \%$ and the $1 \%$ caustic soda solubility from $19.6 \%-25.1 \%$. while, [30] reported high cellulose contents which can lead to high pulp yield. They further reported high ligin contents suggesting high liquor consumption and long cooking cycle. However, the major problem of bamboo pulping is silica deposition according to [31].

vi.Production of Pulp and Paper from Agricultural Residues

One of the major options available to countries with substantial agricultural produce is the production of paper from agricultural wastes. In India, three categories of pulp and paper mills are recognized. These are forest based mills; agro residues based mills and recycle fiber based mills [32]. In 1992, forest based mills accounted for $49 \%$ of total raw materials input for paper, paperboard and newsprint production while agricultural residues and wastes paper accounted for $29 \%$ and $22 \%$ respectively [33] In India, the consumption share of forest based materials has been declining overtime. The share of agricultural residues shows a steadily increasing trend since 1980 and it is expected to rise further in the future [32]. The small paper mills set up in the early 1970's almost exclusively use agro raw materials/residues such as rice straws, wheat straw, and baggase which are relatively short cycle regenerative and abundant [34].; [35], this therefore necessitated the suggestion made by [36] that developing countries like Nigeria should re-strategies and promote paper production processes that depend more on local raw materials to ensure the sustainability of the industry. 
Table 3. Comparative assessment of Fibre Characteristics of Newbouldialaevis and other woody and fibrous materials.

\begin{tabular}{lllll}
\hline S/no & Woody and Nonwoodyfibre & Fibre Length $(\mathbf{m m})$ & Fibre Diameter $(\boldsymbol{\mu m})$ & Lumen Width( $\boldsymbol{\mu m})$ \\
\hline 1 & Moringaoleifera [37]. & 2.20 & 19.50 & 13.70 \\
2 & Newbouldialaevis [28]. & 2.23 & 19.74 & 14.78 \\
3 & Newbouldialaevis [36c]. & 2.31 & 19.54 & 14.57 \\
4 & Bambusa vulgaris (Bamboo) [36a]. & 2.88 & 14.80 & 9.55 \\
5 & Saccharun officinarum (Sugarcane bagasse) [36b]. & 1.62 & 20.78 & 13.26 \\
6 & Thaumatococcusdanielli (Sweet Prayers Plant) [10]. & 2.54 & 15.45 & - \\
7 & Bamboo [38]. & 2.7 & 15.0 & - \\
8 & Hibiscus cannabinus (Kenafbastfibre) [38]. & 2.6 & 20.0 & - \\
9 & Chorchoruscapsularis (Jute) [38]. & 2.5 & 20.0 & 6.03 \\
10 & Abelmoschusesculentus (okra bark) [39]. & 3.49 & 34.87 & 5.80 \\
11 & Hibiscus cannabinus (Kenaf) [39]. & 2.90 & 4.30 \\
12 & Bombaxbuonopozense(Gold coast Bombax) [39]. & 3.83 & 29.85 & 8.49 \\
13 & Musa sapentium (bark) [39]. & 4.48 & 30.16 & 20.38 \\
14 & Steculiaroblonga (yellow steculia bark) [39]. & 3.27 & 28.53 & - \\
15 & Steculiarsetigera [25] & 2.56 & 26.32 & \\
16 & Reed (Arundodonax) [38] & 1.8 & 20 & \\
\hline
\end{tabular}

Source, [37]

Table 3. Continued.

\begin{tabular}{lllll}
\hline S/no & Cellwall Thickness $(\boldsymbol{\mu m})$ & Runkel Ratio2 $\mathbf{x}$ CW/LW & Felting Coefficient FL/FD & Flexibility RatioLW/FDx100(\%) \\
\hline 1 & 2.30 & 0.30 & 119.30 & 66.70 \\
2 & 2.58 & 0.32 & 120.23 & 75.67 \\
3 & 2.48 & 0.31 & 119.30 & 74.70 \\
4 & 2.52 & 0.55 & 112.55 & 64.62 \\
5 & 7.52 & 0.57 & 76.73 & 63.81 \\
6 & 8.56 & 0.81 & 165.48 & 22 \\
7 & - & - & 180 & - \\
8 & - & - & 130 & - \\
9 & - & - & 135 & - \\
10 & 19.62 & 0.78 & 100 & 22 \\
11 & 16.0 & 0.76 & 105.1 & 21 \\
12 & 18.25 & 0.68 & 114.1 & 20 \\
13 & 21.44 & 0.42 & 149.1 & 15 \\
14 & 11.54 & 1.77 & 115.1 & 30 \\
15 & 2.94 & 0.29 & 98 & 78 \\
16 & - & - & 90.0 & - \\
\hline
\end{tabular}

Source, [37]

\section{Conclusion}

The rate of paper consumption determines the level of illiteracy of a nation and the importance of paper and newsprint to national development cannot be overemphasized. However, Nigeria paper industry has not reached the optimum performance level expected of it by planners despite the huge money spent on the establishment of pulp and paper mills in the country before it finally stop production in 1996. Despite the problem associated with process of the Bureau for Public Enterprise (BPE) for the privatization of the integrated pulp and paper mills to be meaningful, it is imperative that efforts should be made to promote production of long fiber pulp locally. Any of the indigenous long fiber wood species discussed in this write up offers great potentials. As the total output from the integrated mills cannot satisfy local demand even if they are to function at maximum capacity, there is need to increase pulp and paper capacities locally by encouraging small scale paper mills to come on board. Small scale pulp and paper mills will provide opportunities for training managerial and technical personnel on several areas of pulp and paper production.

\section{Recommendations}

The under listed recommendations will help to attain a successful and sustainable wood production for pulp, paper and newsprint in Nigeria. They include among others:

i. Government should encourage private sector participation in paper production in the country. Private sector fund should be injected into the manufacturing of pulp and paper products.

ii. To improve the participation in paper production in the country effort should be intensify at promoting selfsustenance in long fibre wood pulp production locally.

iii. Government should show commitment to the provision of conducive operating environment by ensuing power sector reactivation and infrastructural resuscitation.

iv.Government should provide an enabling environment that will attract private investor in forest plantation 
development and newsprint manufacture.

v. Nigeria Paper Mill, Jebba (NPM), Nigerian Newsprint Industry, Oku Iboku and Iwopin Pulp and Paper Company (IPPC) should be resuscitated very fast. The Bureau for Public Enterprise (BPE) should prevail on the new owners of the mills to expedite action on it resuscitation so that pulp, paper and newsprint production can commence without further delay.

vi.Pulp wood plantation, development of Gmelina arborea, Pinus aribeanetc, should be reviewed and sustain by the Federal, State and Local Governments and other stakeholders once the pulp and paper mills start production, government should protect it by restricting importation of pulp and paper products.

vii. The development and utilization of local raw materials resources for use in pulp and paper production will help find a sustainable solution to the problem of the sector.

\section{References}

[1] Picornelli, P. M. (1984): Protecting new pulp and paper industries: an opinion from developing countries. Unasylva 144: pp 54-62.

[2] Ogunwusi A. A. (2011): Strategies for increasing pulp and paper capacity in Nigeria. Journal of tropical forest resources 27 (1), pp 31-46.

[3] CBN (1994): Annual Report of the Central Bank of Nigeria, 1994.

[4] CBN (1990): Annual Report of the Central Bank of Nigeria, 1990.

[5] CBN (1992): Annual Report of the Central Bank of Nigeria, 1992.

[6] Rotowa, O.J. (2013): Declining paper industries: A threat to Nigeria Economy. A seminar paper presented in the Department of Forestry Wildlife and Fisheries, Faculty of Agriculture, Nasarawa State University Keffi. 48pp.

[7] Osadare A. O. (1997): Strategies For Long Fiber Pulp Production In Nigeria. Nig. Jour. For. 24(1 and 2). Pp 16-20.

[8] RMRDC (2009): Raw Materials Sourcing for Manufacturing in Nigeria. $4^{\text {th }}$ Edition. RMRDC publication.

[9] Alao J. S. (2005): Capacity building modules in the Nigeria forest services. A PhD thesis submitted to the Forest Resources Management, University of Ibadan, Nigeria 301 pp.

[10] Sotannde, A. O. (2000): Preliminary Investigation into the Fibre Characteristics of Thaumatococcusdanielli. A dissertation submitted to the Department of Forest Resource Management for the award of Bachelor of Forestry Degree, University of Ibadan. $59 \mathrm{p}$.

[11] Alao, J. S. and Egbewole, Z. T. (2010): Sustainable woodproduction and the economics of newsprint in Nigeria. Practical issues in forestry and wildlife resource. Pp 317-33.

[12] Dinwoodie, J. M. (1965): Relationship between fiber morphology and paper properties; A review of Literature. Tappi 48(8), pp 440-447.
[13] Casey, J. P (1980): Pulp and Paper Chemistry and Chemical Technology. Inter-science publishers.

[14] Ojo, G. O. A. (1971): Thoughts on tree improvement program for some savanna plantaion species. In S. Kolade Adeyoju and M. A. Odeyinde (ed) Proceedings of the Second Annual Conference of the Forestry Association of Nigeria. Zaria 17$20^{\text {th }}$ August, 1971 pp 146-150.

[15] Momoh, Z. O. (1970): The problems of Mycorrhiza establishment in the savanna zone in Nigeria. Paper Presented at the inaugural Conference of the Forestry Association of Nigeria, 1970.

[16] Momoh, Z. O. (1971): Pathological consideration in the economics of plantation establishments. In S. Kolade Adeyoju and M. O Odeyinde (ed) Proceeding of the Second Annual Conference of the thus Forestry Association of Nigeria, Zaria. $17-20^{\text {th }}$ August, 1971. pp 9-14.

[17] Jackson, J. K. (1971): Nursery Techniques in the Savanna Region of Nigeria. In S. Kolade Adeyoju and M. O. Oderinde [ed] Proceeding of the second annual conference of the Forestry Association of Nigeria, Zaria. 17-20 $0^{\text {th }}$ August, 1971. Pp 60-71.

[18] Madu, A. S (1971): Nurseries and Plantations Diseases. FAO Report No. 1823.

[19] RMRDC [1991]; Report of the Muliti-Disciplinary Task Force on Pulp, Paper, Paper Production, Printing and Publishing Sector. RMRDC Publication, 1991. Waste Paper Trade and Recycling in India, Jodhpur, India Scientific Publishers.

[20] Udohitinah and Oluwadare (2001). "Kenafkraft pulp". Bio Resources 6(1), pp 751-761.

[21] Mohd Ederozey. A. M. Akil, H. M, Azhar and ZainalAriffinn, M. I. (2007): Chemical Modification of Kenaf Materials Letters, vol (61), pp 2023-2025.

[22] Ververis C., Georghiou, K, Cristodoulakis, N., Santas, P. and Santas R. (2009). Fibre dimensions, Lignin, and cellulose content of various plan materials and their suitability for paper production." Ind. Cropsprod. 19, 245-254.

[23] Nkaa, F. A. Ogbonnaya, C. I. and N. B. (2004): "Effect of differential irrigation on physical and histochemical properties of Kenaf (Hibiscus cannabinus I.) Grown in the field in Eastern Nigeria," African J Agric. Resh 2 (6), pp 252-260.

[24] Ates, S. N., Akgui, $M$ and Tozloglu, A. (2008): Characterization and evaluation of Paulownia elongate as a raw material for paper production. African J. Biotechnol. Vol (7), pp 4153-4158.

[25] Oluwadare, A. O. and Egbewole, Z. T. (2008): Wood Quality Studies in Plantation Grown Steculia (Steculiasetigera) in the Guinea Savannah, Nigeria. Research Journal of Forestry. Vol (2): pp 22-33.

[26] Bublitz, J. W. (1980): Pulpwood. In J. P Casey (Ed) Pulp Chemistry and Chemical Technology. Wiley Inter-science Publication. Pp 13-159.

[27] Osadare, A. O. (1996): Basic Wood and Pulp Properties of Nigerian-Grown Caribbean Pine (Pinuscaribea) and their Relationships with Tree Growth Indices. $\mathrm{PhD}$ thesis, Department of Agricultural engineering, University of Ibadan, $417 \mathrm{p}$. 
[28] Egbewole, Z. T., Rotowa O. J. and Suleiman A. I. (2016a): Assessment of fibre quality of Newbouldialaevis ( $p$. beav) for pulp and paper making. Journal of Forest Science and Environment (JFSE). A publication of Department of Forestry and Wildlife, Faculty of Agriculture, University of Maiduguri, Borno State, Nigeria. June, 2016, J. For. Sci. Env. (2016) Vol. 1 (1): 21-30.

[29] Ogunwusi, A. A and Uwajeh A. P. (2009): Indicative inventory of bamboo availability and utilization in Nigeria. JORDIN 9(2), pp 1-9.

[30] Ogunsile, B. O and C. Uwajeh (2009): Evaluation of pulp and paper potentials of a Nigerian grown Bambusa vulgaris. World Applied Science Journal 6(4) 536-541.

[31] Andtbacka, S. (2005): A. fiber line design for bamboo pulping.

http://www.tapsa.co.za/archieve2/joournalpapers/bamboopulpi ng.htmlretrieved June, 2012.

[32] Schumacher K., and Sathaye, J. (1999): India's pulp and paper industry: Productivity and Efficiency. A Report of the Earnest Orlando Lawrence Berkerly National Laboratory. LBNL41843 pp 37.

[33] Sharma, Vinod K., K. V. Ramaswamy. R. R. Vaidaya, N. Hadker and P. van Beukering (1998). The Indian Paper industry In P. van Beukering, Peter van, Vinod K. Sharma (ed).
[34] King, K. F. S. [1977): Political Economy of Pulp and Paper. Unasylva 29 (19): pp 6-9.

[35] Patil, J. V., Appaji Chari, Rao, S. V., Maththur, R. M., Vimelesh, B. and Lal, P. S. (2011): High Biomass Sorghum (Sorghum bicolor) - An Alternative Raw Material for Pulp and Paper Making In India. IPPTAJ. 23(2): pp 161-165.

[36] EgbewoleZ. T., Omoake, P. O. and Rotowa O. J. (2015): Fibre Quality Assessment of Saccharum officinarum (Sugarcane) Bagasse as a Raw Material for Pulp and Paper Production. NSUK Journal of Science and Technology (NJST). Publication of Nasarawa State University, Keffi. www.njst@nsuk.edu.ng Vol. 5(2), 2015. ISSN 1597-5527. Pp 142-149.

[37] Egbewole, Z. T., Rotowa, O. J., and Adegoke, I. A. (2017). Wood Quality Study of Plantation Grown Moringa (Moringaoleifera Lam) in the Middle Belt Region of Nigeria. International Journal of Applied Research and Technology. 6(6): 3-13.

[38] Pande, H. (1998): Non Wood Fibre and Global Fibre Supply. Unasylva 193 (46): pp 44-50.

[39] Osadare, A. O. and Udohitinah, J. S. (1993): Fibre Characteristics of some Nigerian RawMaterials for Long Fibre Pulp Production. In: Forestry for Urban and Rural Development in Nigeria, Oduwaiye, E. A. (Ed). FAN $23^{\text {rd }}$ Conference, pp: 132-138. 